\title{
Determinants of Turnover Intention in the Private Universities in Malaysia: A Conceptual Paper
}

\author{
Chitra Devi Ainer ${ }^{1}$, Chandrakantan Subramaniam ${ }^{2}$, and Lawrence Arokiasamy ${ }^{3}$ \\ ${ }^{1}$ Faculty of Educational Studies, 43400 University Putra Malaysia \\ ${ }^{2}$ College of Business, 06010 University Utara Malaysia \\ ${ }^{3}$ Faculty of Business \& Law, 50480 International University of Malaya-Wales
}

\begin{abstract}
Turnover intentions in academic institutions has become one of the main concern of the management as surviving and achieving excellence is very much about having the knowledgeable and committed employee. Therefore, it is one of the main and foremost issue for a management of higher education institution to give important. There are many factors that influence an academician to have turnover intentions. Hence, this study's focus was to investigate the relationship between role ambiguity, work-overload, work family conflict, co-workers warmth, co-workers competence and turnover intentions. The variables studied in this paper were analyse from a research framework. The finding of this study has been discussed on role ambiguity, work-overload, work family conflict, co-workers warmth, co-workers competence and turnover intentions. Conclusion has been drawn from the support of literature that states that the variables influences on turnover intentions. This paper's finding provides valuable guidance for researcher and practitioners to overcome and improve the current mechanism to reduce turnover intentions. The research has also found few new paths for thinking on how to manage employees that having turnover intentions in any organizations.
\end{abstract}

Keywords - role ambiguity, work-overload and work-family conflict, co-workers' warmth and coworker's competence and turnover intentions

\section{Introduction}

Turnover of academicians is one of the main and foremost issue the management of higher education institution should emphasis on. Sustaining in the education industry with on-going development in research and teaching is one of the top priority of any private higher education institution and to do so retaining the academic staff is the key to achieve the mission. As the options to leave the current institution are in the hands of the academician due the number of private higher institutions keep increasing from year to year. It is the utmost asset of an education intuition is to have talented academician and to sustain them. Furthermore, losing talented academicians is the most damaging and influencing factors in reduction of research output and the image of an institution as higher education due to the rank of a university lies on the hands of knowledgeable and committed academics (Robyn, \& Du Preez, 2013).

The establishment of Private Higher Educational Institutions Act 1996, Act 555 "Prior approval of the Minister shall be obtained for the establishment of a private higher educational institution with the status of a University or University College or a branch campus thereof or a branch campus of a foreign University or University College" many private higher education institution existed in Malaysia but only after the announcement of Private Higher Educational Institutions Bill, National Council on Higher Education Bill and National Accreditation Board Bill by Malaysian Government whereby the PHEIs can confer their own degree, the education industry in Malaysia has grown rapidly since then (Ministry of Education (MOE), 2015). In early 2017, there were 73 private universities (inclusive the branch campus), 37 private university-colleges and 382 private colleges in Malaysia registered under the Malaysian Qualifications Register (MQA, 2017). All these private higher education institutions offer varies degrees from certificates to postgraduate degrees.

Table 1 below shows the total number of academic staff according to institutions and year from 2012 to 2015 . It is clearly stated that in 2013 the total academician in private HEIs is 24,476 which increased rapidly in numbers to 36,185 academic staff. This can be relating back to the rapid growth of private higher education industries as mentioned above. In 2015 , the number of academician drop from 36,185 to 34,750 in comparison to other HEIs category the number is very visible for private HEIs. This clears shows that turnover among private HEIs academician is rather high comparing to other HEIs category. 
Ajzen, I. (1991)Table 1: Number academic staff in Malaysia

\begin{tabular}{|c|c|c|c|c|}
\hline HEIs Category & 2012 & 2013 & 2014 & 2015 \\
\hline IPTA & 29,769 & 32,516 & 31,917 & 31,877 \\
\hline IPTS & No record & 24,476 & 36,185 & 34,750 \\
\hline Politeknik & 7,306 & 7,256 & 7,160 & 7,391 \\
\hline Kolej Komuniti & 2,751 & 2,816 & 2,727 & 2,696 \\
\hline
\end{tabular}

Source: Institusi Pendidikan Tinggi.

As a whole, turnover intentions is considered one of important element that need to be given importance too to sustain in the education industry. The aim of this study is to identify on whether the stressors and relationship with coworkers has any contribution to turnover intention.

Turnover intentions spell catastrophe for most of the organizations due to the high cost, the actual time wasted in recruitment of employee and both money and time spent in training and development for new staff. Retention and talent development in an organization can be sustained or maintained when the management team concentrate on turnover intentions rather than the actual turnover as loss of employees involved higher cost (Hasin, \& Omar, 2007). It is estimated that in average an organization considerably bare a cost of 93 to 200 percent over turnover of an employee's annual salary on a specific job (Cascio, 2000). Therefore, turnover has an impactful effect on any organization and it is considered very crucial for management to pay attention in order to avoid loss in terms of financial, resources and time.

This intention to leave can be exploited as an indicator of actual turnover based on the theory of planned behavior (Ajzen, 1991) where this intention is said to be the most prompt determinants of real behavior (Alam, \& Mohammad, 2010). This intention will create a negative influence to an organization as the employee has detached from the commitment to work subsequently resulting the performance of the said employee will deteriorate and pulling down the organization's performance in total. This can also be expressed clearly by using social exchange theory (SET) (Homans, 1958) where employees tend to weigh the potential benefits versus risks of social relationships and decide to abandon or terminate the relationship when risk out rule the benefits.

There is another impacting element that relate to turnover intention, studies have shown that high staff turnover is regularly the outcome of a poor working environment (Hinkin, \& Tracey, 2000), and that relationships with management team and other staff members constitute a standout amongst the most noteworthy determinants that influencing staff turnover (Collins, 2010) and subsequently, subordinates are influenced by their management team (Susskind, Macmar, \& Borchgrevink, 2007). Role ambiguity, conflict and overload may cause the development of stress symptoms. A review by (Kinman, 2001) revealed that a high proportion of academicians have strong desire to leave higher education and or regret choosing an academic career. This has potentially serious implications not only for the individuals themselves, but also for the quality of higher education.

Turnover is an employee's stable move beyond the boundary of the organization (Carmeli, \& Weisberg, 2006). The term turnover intentions is discuss into three specific fundamentals in the cognition withdrawal process example thoughts of quitting the job, the intention to search for a new or different job and then the intention to quit. Turnover of critical employee is considered damaging to the organization in terms of suppression of cost and work interruption (Addae, Parboteeah, \& Davis, 2006). Thus, it has become most studied area (Yousaf, 2008). Although the difference in between intention to leave and actual turnover may vary but researchers identify that the intention to leave has more immediate consequence on turnover decision (Addae, Parboteeah, \& Davis, 2006).

Turnover intentions are one of the most researched factor by researchers due to the significances of this intentions to an organization in which it lower the efficiency of an organization due to replacement of the employee, loss of talented workforce, loss of organizational funds and loss of experience (Addae, Parboteeah, \& Davis, 2006) . As an organization may confront a possible cost due to employee's poor performance and their intentions to leave, it is very much argued that it is important and will surely benefit the organizations to study the factor that affecting employee's dissatisfaction which lead to poor performance and intentions to quit. Furthermore, turnover intentions are also said to be the "strongest cognitive predecessor of (actual) turnover with the great explanatory power" (Griffeth, Hom, \& Gaertner 2000).

As turnover intentions has a significant effect on any organization, this study was carried out to identify the influence of stressor factor namely role ambiguity, work-overload and work-family conflict and relationship with coworkers factors namely co-workers' warmth and co-worker's competence in turnover intentions. There has been many research conducted on stressors factors which show the significant relationship between turnover intentions. Role ambiguity and role conflict has a negative correlation between job satisfactions which eventually lead to turnover intentions ( $\mathrm{Wu} \&$ Norman 2006). Another researcher has also proves that increase in role ambiguity has a positive relationship in turnover intentions (Kevin Hill, 2015). The constructs of warmth and competence were vastly used when 
describing an individuals or group and about $80 \%$ of this impression developed from this two constructs (Cuddy, Glick \& Beninger 2011).

There have been many studies conducted to identify the influencing factors to turnover intentions. Many variables were used to determine the factors influencing turnover intentions such as work related identity, personal disaffection, burnout (emotional exhaustion, depersonalization, reduced individual achievement), three dimensions of work engagement (vigor, dedication and absorption) and not only relate to chain of resources and demands, gender differences, job satisfaction, problematic customers (Bakker \& Demerouti, 2007).

Many researchers have put inputs to study turnover intentions by combining variables to understand the factors that most influence the turnover intentions. While intentions are a subsequent effect of behaviour the actually determinant of such intentions is still unknown (Firth, et. al 2004). Therefore, this research is believe to provide an understanding on the ways to overcome the turnover intentions and an idea to employers on how to overcome with possible remedies to avoid turnover intentions.

\subsection{Research Question}

What are the factors influences turnover intentions among academicians towards private universities in Malaysia.

\section{Literature Reviews}

\subsection{Turnover Intention (TI)}

Turnover intentions and retention are very important issues that will affect an organizations in many ways. In this context, it is important to cite Andrew Carnegie an industrialist from 19th century who stated that "Take away my people, but leave my factories and soon grass will grow on the factory floors, take away my factories, but leave my people and soon we will have a new and better factory." This statement clearly state the importance of employee and the sustainability of employees for an organization to grow.

Turnover intention is rarely explained in any reported studies, it is stated that turnover intentions is perhaps attributable to the theory that people identify the term to be self-explanatory (Klopper, et. al 2012). Another researcher has defined turnover intentions into two category which is voluntary and involuntary turnover (James, 2001). Voluntary turnover is when an employee leaves the organization on his on willing and involuntary turnover is when an employer removes the employee from the organization. Turnover cost can be divided into two which are visible and invisible cost (Ahlrichs, 2000). Visible turnover consist of leave capitalization, employment, reference check, security clearance, parttimer, moving cost, training and orientation expenses and invisible cost includes expansion of HR division, loss of production, and informal training.

Turnover intentions is a process that consist of few stages. This process involve psychological factor, cognitive factor and behavioural factor (Takase, Oba, \& Yamashita, 2009). In first stage, disappointment and dissatisfaction towards the issues occur in an organization cause emotional drawbacks and less interaction towards work commitment, at stage two employee start to think and reasoning which is the main cause of turnover intentions. Many researchers mentioned that turnover intentions as cognitive expression result of turnover whereby the cognitive will change into behaviour which is the stage three factor. At this stage employee will react or express their intentions to leave the job by showing their less commitment, low productivity and most of the time they will be absent to work. Employees normally decide to leave the job on the current work situation, work related issues and alternative that they have on hand. If the outcome is positive for the said employee then turnover will be the result for the decision making process (Meeusen, Van Dam, Brown-Mahoney, Van Zundert, \& Knape, 2011).

\subsection{Role Ambiguity (RA)}

Role ambiguity is a perception that elaborate work related information (Abdullah, Ahsan, \& Alam, 2009). An employee must have a clear knowledge of what is expected, the job responsibility, the position, and the rights. Role ambiguity is when an employee does not have any information on what is required or to be done at work. Accordingly to the researcher, lack of information can result from two situations, first the required information does not exist or secondly the information exists but it is not made available for the employee.

Role ambiguity is defined as the presence of absence of clear knowledge of the role an employee is required to complete (Judeh, 2011). Since an employee needs to have a clear picture of what he or she need to do, the not clear direction on one's role will lead to job related stress and directly affect the job satisfaction and subsequently lead to turnover intentions. Another researcher stated that role ambiguity is an opinion or perception that an employee is lacking of required information to get the assigned work done which lead to the employee feeling stranded. This uncertainty of an employee about his or her role is role ambiguity (Onyemah, 2008).

Many studies was conducted on turnover intentions that caused by few levels of job stress which is one of the reason on why people leave their jobs (Maertz, \& Kmitta, 2012). Somehow, study on role ambiguity by itself still remains comparatively absent from theoretical models of turnover and empirical tests. For this reason, role ambiguity can be studied to better understand the effect of factor in employee's turnover intentions (Claessens, Eerde, Rutte, \& Roe, 2004). A 
study conducted by Kevin Hill, (2015) revealed that role ambiguity is an antecedent of intention to quit over the time with mediated by increase in relationship conflict which in other word can be mentioned is work family conflict. In relation to the mentioned literature reviews, role ambiguity or in other word role clarity can lead to low turnover intentions. One who has a better understanding on what is required out of him at work will be more content in comparison with one who is not clear of what is required out of him at work which eventually lead him to have turnover intentions. In line with past literature reviews on role clariy, the first proposition assumes that:

\subsection{Work-overload (WO)}

A study that was conducted in UK shown that majority of employees was not happy with their current working hours whereby they were required to work extra hours and overloaded work while concurrently meet the target and deadlines. Work overload was also defined as having too many tasks to be completed in too little time (Claessens, Eerde, Rutte, \& Roe, 2004).

The first and foremost effect of work overload is that it is the predictor of burnout and work family conflict (Britt, \& Dawson, 2005). Work overload is an interface between the real work request and the emotional draining accumulated from the struggle to meet the demand (Bliese, \& Castro, 2000). The emotional draining turn into bigger or greater when the employee sees or feel that the work load is greater than their capabilities.

Work overload is the most important source of work related stress which leads to turnover intentions (Hon, Chan, \& Lu, 2013). This situation of work overload has been a major issue or problem in an organizations total productivity (Duxbury, \& Higgins, 2001). The impact of stressors (work-load) to turnover intentions has an indirect relationship. The stressors factor has a direct impact on management support which effect the job satisfaction, job commitment and job stress which then lead to turnover intentions. This null relationship from work-overload to turnover intentions has been shown in past research by (Tinker, \& Moore, 2001) whereby the indirect stressors effecting one's health and indirectly contributing to turnover intentions (Firth, Mellor, Moore, \& Loquet, 2004).

In most of the research conducted, work overload has positive relationship with turnover intentions. The current study shows that there is a negative significant relationship between work-overload and turnover intentions. The possibilities of this results may derived from the majority of participants who falls under the age group of 36 years to 45 years, which carries the total percentage of $55.5 \%$ from 189 participants. The selection, optimization and compensation (SOC) theory is one of the mechanisms that administer the general functions of development which is up keeping, progression and compensating for loss (Baltes, Briggs, Huff, Wright, \& Neuman, 1999). Selection includes confining action on area one feels at ease, optimization assumes that one attempts to achieve the higher level of functioning and compensations refer to how one attain the goal accordingly to their capabilities. This mechanisms come into action throughout everyone's life but particularly later of their career or as we age. Whereby career growth is very much important and addition work is considered as a possibilities to grow. In line with the above discussed literature reviews, the second proposition assumes that:

\subsection{Work-family conflict (WFC)}

It is estimated that $52 \%$ of employees going thru work-to-family conflict (American Psychological Association, 2007). The minute work and family factors interfere with one another, there will be damaging outcome to an individual's mental state, health, behaviors and the individual's performance at work and the family (Amstad, Meier, Fasel, Elfering, \& Semmer, 2011). Therefore it is significant to understand the factors that contributing to work-family conflict to significantly reduce the cost to the specific individual, management and family. Work-family conflict is also define as the collision in between pressures and demands at work and pressures and demands in family (Kahn, Wolfe, Quinn, Snoek, \& Rosenthal, 1964).

The work-family conflict can be divided into three dimensions which is time based dimensions, strain based dimensions and behavior based dimensions (Greenhaus, \& Beutell, 1985). Time base dimensions indicating the excessive usage of time or the hours spent at work, the strain based dimensions is all the stress factors comprising anxiety, fatigue, depression and irritability caused by work or at work and the third is the behavior based dimensions with consist of selfconfidence, emotional stability, aggressiveness and objectiveness both in the family and at work. Understanding the work-family conflict and solving this issue is very important as it will help the employee to achieve balance in at work and family commitments (Burke, Fiksenbaum, El-Kot, Koyuncu, \& Jing, 2011).

The higher the job responsibilities of an employee, the greater the level of conflict that can be experience by an individual at family and it is vice-versa (Cinamon, 2006). Conversely, conflict does not only occur from work aspects to family aspects as it depends on once involvement in both the aspects. In comparison to the above discussed review, the result is in line with the researcher's outcome. Thus, the third proposition is formulated based on majority of past research.

\subsection{Co-workers' Warmth (CWW)}

The most important factors that lead to social assessments on other individuals or a groups of people are identified as warmth and competence (Fiske, Cuddy, Glick, \& Xu, 2002). This factors of warmth and competence are so dominant that over $75 \%$ of people intent to fall under the warmth and competence factors when the describe people (Abele, Uchronski, Suitner, \& Wojciszke, 2008). 
Individuals who are warmth naturally known as compassionate and considerate person with a very strong ethics and they normally cares and co-operate with others. People has the understanding that warmth is naturally understood as social and moral behaviours (Fiske, Cuddy, \& Glick, 2007). Warmth is also includes teamwork among the individuals and that it is mostly collaborated with servicing or caring field (Brambilla, Hewstone, \& Colucci, 2013).

Warmth and competence were extensively used when describing ones emotions about a person and a group (Cuddy, Glick \& Beninger 2011). This author has also describe warmth person as a person with good nature and do not make others feel him as a threat and they will somehow try to build a relationship with others. Almost $80 \%$ of people's descriptions on individual falls under this two factors. Warmth and competence factors contribute or influence one's behaviour and different emotions (Fiske, et. al, 2002). Based on the above-mentioned literature reviews, the current research assumes the following proposition.

\subsection{Co-workers' Competence (CWC)}

Competence has a different view or different understanding in different countries (Cheng, Dainty, \& Moore, 2003). Competence is a qualities that is required by someone to complete an assigned. Individual or group of people who are competent aim for high level of achievement and normally known as self-determining with the capacity to perform and capable to lead and control others, in other word competence is a measurement to be used on person who are independent, individualistic and have the possibility to dominate and control their own situation (Abele, et. al 2008).

Competent person or individuals are more individualistic and job-orientated individual (Cuddy, Glick \& Beninger 2011). Competent person will do things independently and normally has the tendency of controlling the environment around them, they are capable of performing at the peak and will lead and control the others (Abele, et. al 2008). Competence was explained as familiarity, expertise, capabilities, and other individualities that is required to complete a task efficiently (Campion, Fink, Ruggeberg, Carr, Phillips, \& Odman, 2011). Competence were categorized into four aspects of professional, self-competence, social, and methodological (Kauffeld, 2006).

Professional in this context refer to abilities and information an employee has to complete a task and the capability to detect the room for advancement in the organization. (Heinen, 2011). Self-competence refers to capability of an individual to self-analyze and develop their standards and behaviors to the direction of their work improvement developed (Frey, \& Ruppert, 2013). Social is familiarity, information, and skill of an employee in coping with the many social interaction. In comparison to the above discussed literature reviews, the result is in line with the researcher's outcome, therefore the fifty proposition assumes that

\section{Research Framework}

The research framework is a conceptual model of a theory with few or several predictors which has identified to be significant on one identified research problem (Sekaran, 2005). This study was conducted to investigate the relationship in between the independent variables of role ambiguity, work-overload, work family conflict, co-workers warmth, coworkers competence and dependent variables of turnover intentions. A comprehensive framework was developed based on the support of literature reviews. The framework comprises of five independent variables which will be tested on the relationship or the influencing level towards dependent variable of turnover intentions as shown in Figure 1.

Figure 1: Research Framework

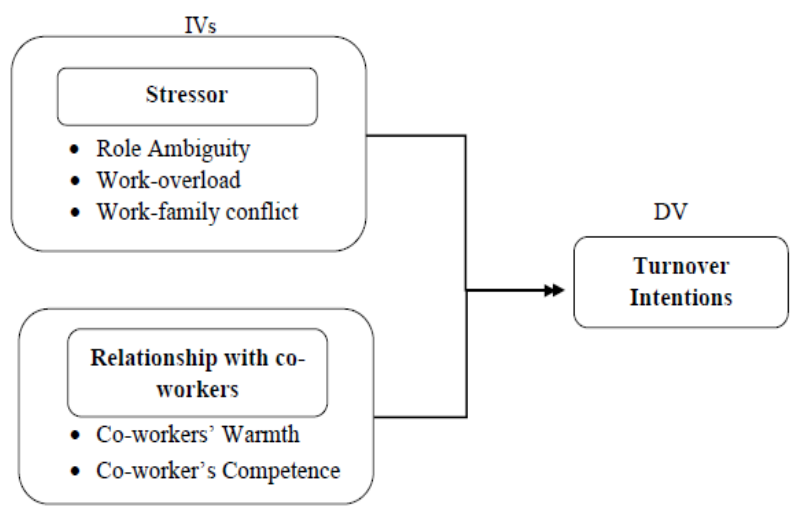

\section{Conclusions}

The turnover intentions has a very significant effect on organization's cost. There are many negative consequences due to turnover intentions for any organization. Having high skilled employees leaving the organizations may have a very disrupting consequences or implications. For an example impaired organizational functioning, poor delivery 
in service and lack of systematic administration or delay in administrative task. Losing high skilled employees may result in increased in hiring cost and re-training employees (Sulu, Ceylan, \& Kaynak, 2010).

Turnover rate in a company is measure of how a corporate business is fostering positive culture that includes recognition, leadership opportunities, maintaining a good relationship and instilling motivation to work. The work demand from the higher private institution may also be an inducing factor. The results of this study highlighted the role ambiguity, work overload, work-family conflict, co-worker warmth and co-worker competence, were important factors to understand turnover intentions among academicians in private higher education institutions. Therefore, it is encourage for the management to explore these factors to have a better organizational skill to overcome turnover intentions issues.

This study also indicates that it is may be useful to other work institution for example, managers and senior officials, professional's occupations, associate professionals and technical occupations, administrative and secretarial occupations, and sales and customer service occupations to recognize the paramount for preventing high turnover in any organization.

\section{Implications}

The present study's aim was to find out on whether there is a significant relationship between stressors namely role ambiguity, work-overload and work-family conflict to turnover intentions and to find out on whether there is a relationship with co-workers namely co-workers' warmth and co-worker's competence influence turnover intentions among academicians towards their institution. Many previous research was conducted in various industries by researchers to understand on what actually determine the turnover intentions by using possible antecedents of intentions to leave (Firth, et. al 2004). For example factors like job satisfaction and organizational commitment were used to study the turnover intentions (Alexandrov, Babakus, \& Ugur, 2007). The current study has revealed that role ambiguity, work overload, work-family conflict, co-worker warmth, and co-worker competence could be used as one of the variables to relate to employees' turnover intentions. One's behaviour is always driven by their perceptions or insight on a situation (Meyer, \& Allen, 1991)

These variables are among other factors that seems to be normally related to turnover intentions. Therefore, the current study was extended to academic industry to measure the reliability of three stressors variables such as role ambiguity, work-overload and work-family conflict and two relationship with co-workers variables such as co-workers' warmth and co-worker's competence which influence on the research academically. Furthermore, this study was conducted among academician in one private higher education institution which make rooms for researchers to conduct study on public higher education institution to prove the influences of stressors and relationship with co-worker to turnover intentions. This research would be very much worthy and adds significance to the academic world due to the lack of study among academicians in Malaysia. Theoretically, the findings of the study directing to the management of this private higher education institution that they should give importance to role ambiguity and work-family conflict, co-workers' warmth and co-worker's competence in order to prevent turnover intentions.

This research provide few new paths for thinking on how to manage employees that having turnover intentions in any organizations. Firstly, as the effect of turnover to any organization is very significant the organizational decision makers should re-think on the effect of a decision on employee. So endorsing any policies or decision should be made by considering the implication on long run. For example, decision makers should take into consideration of role ambiguity factor to reduce turnover intentions among employees in a form of more general approach to human resource management. By doing so role ambiguity issue can be somehow overcome and may result in reduce of turnover intentions. Useful intercessions are required to decrease role ambiguity and should be continued by guided past and present research which plays and important role in managerial interventions.

The second variable is work-family conflict. Empirical research has given evidence that work-family conflict interface to turnover intentions. Therefore, management should always ensure on non-work-family conflict occurs and also understand on up to what level of tolerance an academician can accept before the work family conflict occurs. The third and fourth variables are co-worker warmth, and co-worker competence. The study's findings shows that it is very important to have the behaviours and attitudes that is being portrayed at work place as this has a vast impact on co-workers turnover intentions. The findings shows that having a warmth and competence employees is actually influencing ones turnover intentions. Therefore, employers or management may or should 
pay attention to this two variables during hiring process. Management may well benefit from the use of structured and unstructured interviews to identify the warmth or competence employees besides seeing the academic achievements.

\section{References}

[1] Robyn, A., \& Du Preez, R. (2013). Intention to quit amongst Generation Y academics in higher education. SA Journal of Industrial Psychology39(1), 14.

[2] Hasin, H. H., \& Omar, N. H. (2007). An empirical study on job satisfaction, job-related stress and intention to leave among audit staff in public accounting firms in Melaka. Journal of Financial Reporting \& Accounting, 21-39.

[3] Cascio, W.F. (2000), Costing Human Resources: The Financial Impact of Behavior in Organizations Southwestern Cincinnati, $\mathrm{OH}$.

[4] Ajzen, I. (1991). The theory of planned behavior. Organizational behavior and human decision processes, 50(2), $179-211$.

[5] Alam, M. M., \& Mohammad, J. F. (2010). Level of job satisfaction and intent to leave among Malaysian nurses. Business Intelligence Journal, 3(1), 123-137.

[6] Homans, G. C. (1958). Social behavior as exchange. American journal of sociology, 597-606.

[7] Hinkin, T.R., Tracey, J.B., (2000). The cost of turnover. Cornell Hotel Restaur. Admin.Q. 41(3), 14-21.

[8] Collins, M.D., 2010. The effect of psychological contract fulfillment on manager turnover intentions and its role as a mediator in a casual, limited-service restaurant environment. Int. J. Hosp. Manage. 29, 736-742.

[9] Susskind, A. M., Macmar, K. M., \& Borchgrevink, C. P. (2007). How organizational standards and coworker support improve restaurant service [Electronic version]. Cornell Hotel and Restaurant Administration Quarterly, 48(4), 370-379.

[10] Kinman G. Pressure points: a review of research on stressors and strains in UK academics. Educ Psychol 2001; 21.

[11] Carmeli, A. and Weisberg, J. (2006), "Exploring turnover intentions among three professional groups of employees”, Human Resource Development International, 9(2), 191-206.

[12] Addae, H.M. , Parboteeah, K.P. and Davis, E.E. (2006), "Organizational commitment and intentions to quit: an examination of the moderating effects of psychological contract breach in Trinidad and Tobago", International Journal of Organizational Analysis, 14(3), 225-238.

[13] Yousaf, A. (2008). The role of Organizational justice in the relationship between LMX, Organizational Commitment and Intent to turnover (Master's thesis, University of Twente).

[14] Addae, H.M. , Parboteeah, K.P. and Davis, E.E. (2006), "Organizational commitment and intentions to quit: an examination of the moderating effects of psychological contract breach in Trinidad and Tobago", International Journal of Organizational Analysis, Vol. 14 No. 3, pp. 225-238.

[15] Griffeth, R.W., Hom, P.W. and Gaertner, S. (2000), "A meta-analysis of antecedents and correlates of employee turnover: update, moderator test and research implications for the next millennium", Journal of Management, 26(3), 463-488

[16] Wu, L., \& Norman, I. J. (2006). An investigation of job satisfaction, organizational commitment and role conflict and ambiguity in a sample of Chinese undergraduate nursing students. Nurse Education Today, 26(4), 304-314.

[17] Kevin Hill Denis Chênevert Jean Poitras , (2015)," Changes in relationship conflict as a mediator of the longitudinal relationship between changes in role ambiguity and turnover intentions ", International Journal of Conflict Management, 26(1), $44-67$

[18] Cuddy, A.J.C., Glick, P., Beninger, A., 2011. The dynamics of warmth and competence judgments: and their outcomes in organizations. Res. Organ. Behav. 31, 73-98.

[19] Bakker, A.B. and Demerouti, E. (2007), "The job demands-resources model: state of the art", Journal of Managerial Psychology, 22(3), 309-328.

[20] Firth, L., Mellor, D. J., Moore, K. A., \& Loquet, C. (2004). How can managers reduce employee intention to quit?. Journal of managerial psychology, 19(2), 170-187.

[21] Klopper, H. C., Coetzee, S. K., Pretorius, R., \& Bester, P. (2012). Practice environment, job satisfaction and burnout of critical care nurses in South Africa. Journal of Nursing Management, 20(5), 685-695.

[22] James L. Price, (2001) "Reflections on the determinants of voluntary turnover", International Journal of Manpower, 22(7), $600-624$.

[23] Ahlrichs, N. S. (2000). Competing for Talent: Key Recruitment and Retention Strategies for Becoming an Employer of Choice. Davies-Black Publishing.

[24] Takase, M., Oba, K., \& Yamashita, N. (2009). Generational differences in factors influencing job turnover among Japanese nurses: An exploratory comparative design. International Journal of Nursing Studies, 46(7), 957-967.

[25] Meeusen, V. C., Van Dam, K., Brown-Mahoney, C., Van Zundert, A. A., \& Knape, H. T. (2011). Understanding nurse anesthetists' intention to leave their job: how burnout and job satisfaction mediate the impact of personality and workplace characteristics. Health care management review, 36(2), 155-163.

[26] Abdullah, Z., Ahsan, N., \& Alam, S. S. (2009). The effect of human resource management practices on business performance among private companies in Malaysia. International Journal of Business and Management, 4(6), 65.

[27] Judeh, M. (2011). Role ambiguity and role conflict as mediators of the relationship between socialization and organizational commitment. International Business Research, 4(3), 171.

[28] Onyemah, V. (2008). Role Ambiguity, Role Conflict, and Performance: Empirical Evidence of an Inverted-U Relationship. Journal of Personal Selling \& Sales Management, 28(3), 299-313.

[29] Maertz, C.P. and Kmitta, K.R. (2012), "Integrating turnover reasons and shocks with turnover decision processes", Journal of Vocational Behavior, Vol. 81 No. 1, pp. 26-38.

[30] Yuchi, Z., Yuen, S. M. W. K., Lau, K., Underhill, A. Q., Cornea, R. L., Fessenden, J. D., \& Van Petegem, F. (2015). 
[31] Claessens, B.J.C., Eerde, W.V., Rutte, C.G. and Roe, R.A. (2004), "Planning behavior and perceived control of time at work", Journal of Organizational Behavior, 25, 937-50.

[32] Britt, T.W. and Dawson, C.R. (2005), "Predicting work-family conflict from workload, job attitudes, group attributes, and health: a longitudinal study", Military Psychology, 17, 203-27.

[33] Bliese, P. D., \& Castro, C. A. (2000). Role clarity, work overload, and organizational support: Multilevel evidence of the importance of support. Work and Stress, 14(1), 65-73.

[34] Hon, A. H., Chan, W. W., \& Lu, L. (2013). Overcoming work-related stress and promoting employee creativity in hotel industry: The role of task feedback from supervisor. International Journal of Hospitality Management, 33(1), 416-424.

[35] Duxbury L, Higgins C. Work life in the new millennium: where are we? Where do we need to go? Discussion Paper, Canadian Policy Res Networks; 2001. October. 12.

[36] Tinker, S., \& Moore, K. A. (2001, November). The impact of long work hours on the family-work relationship and health. In Inaugural Conference of Australian Psychological Society Relationships Interest Group, Melbourne (pp. 17-18).

[37] Firth, L., Mellor, D. J., Moore, K. A., \& Loquet, C. (2004). How can managers reduce employee intention to quit?. Journal of managerial psychology, 19(2), 170-187.

[38] Baltes, B. B., Briggs, T. E., Huff, J. W., Wright, J. A., \& Neuman, G. A. (1999). Flexible and compressed workweek schedules: A meta-analysis of their effects on work-related criteria. Journal of Applied Psychology, 84(4), 496.

[39] American Psychological Association. (2007). Stress in America 2007.

[40] Amstad, F. T., Meier, L. L., Fasel, U., Elfering, A., \& Semmer, N. K. (2011). A meta-analysis of work-family conflict and various outcomes with a special emphasis on cross-domain versus matching-domain relations. Journal of Occupational Health Psychology, 16(2), 151-169.

[41] Kahn, R.L., Wolfe, D.N., Quinn, R.P., Snoek, J.D. and Rosenthal, D.A. (1964), Organizational Stress: Studies in Role Conflict and Ambiguity, Wiley, New York, NY

[42] Greenhaus, J. H., \& Beutell, N. J. (1985). Sources of conflict between work and family roles. Academy of Management Review. 10, 76-88.

[43] Burke, R.J., Fiksenbaum, L., El-Kot, G., Koyuncu, M. and Jing, W. (2011), "Potential antecedent and consequences of workfamily conflict: a three country study", in Kaiser, S., Ringlstetter, M.J., Eikhof, D.R. and Cunha, M.P.E. (Eds), Creating Balance? International Perspectives on the Work-Life Integration of Professionals, Springer, Heidelberg and Berlin, 101-119.

[44] Cinamon, R.G. (2006), "Anticipated work-family conflict: effects of gender, self-efficacy, and family background”, The Career Development Quarterly, 54(3), 202-215.

[45] Fiske, S.T., Cuddy, A.J.C., Glick, P., Xu, J., 2002. A model of (often mixed) stereotype content: competence and warmth respectively follow from perceived status and competition. J. Pers. Soc. Psychol. 82(6), 878-902.

[46] Abele, A.E., Uchronski, M., Suitner, C., Wojciszke, B., (2008). Towards an operationalization of the fundamental constructs of agency and communion: trait content ratings in five countries considering valence and frequency of word occurrence. Eur. J. Soc. Psychol. 38, 1202- 1217.

[47] Fiske, S.T., Cuddy, A.J.C., Glick, P., 2007. Universal constructs of social cognition: warmth and competence. Trends Cognit. Sci. 11(2), 77-83.

[48] Brambilla, M., Hewstone, M., Colucci, F.P., (2013). Enhancing moral virtues: increased perceived out group morality as a mediator of intergroup contact effects. Group Process. Intergroup Relat. 16, 648-657.

[49] Cheng, M., Dainty, A.R.J. and Moore, D.R. (2003), "The differing faces of managerial competency in Britain and America", Journal of Management Development, 22(6), 527-537.

[50] Campion, M.A., Fink, A.A., Ruggeberg, B.J., Carr, L., Phillips, G.M. and Odman, R.B. (2011), "Doing competencies well: best practices in competency modeling”, Personnel Psychology, 64(1), 225-262.

[51] Kauffeld, S. (2006), "Self-directed work groups and team competence", Journal of Occupational and Organizational Psychology, 79(1), 1-21.

[52] Heinen, T. (2011), Planung der soziotechnischen Wandlungsfähigkeit in Fabriken, PZH, Garbsen.

[53] Frey, A. and Ruppert, J.-J. (2013), "Structuring and detecting competence", in Beck, K. and Zlatkin-Troitschanskaia, O. (Eds), From Diagnostics to Learning Success, Sense, Rotterdam, Fetzer, S.J., (2003). Professionalism of associate degree nurses: the role of self-actualization. 185-198.

[54] Sekaran, D. (2005). A general guide to writing research proposal and report: A handbook for beginning research: Kisumu: Options Printers and Publishers.

[55] Sulu, S., Ceylan, A., \& Kaynak, R. (2010). Work alienation as a mediator of the relationship between organizational injustice and organizational commitment: Implications for healthcare professionals. International Journal of Business and Management, 5(8), 27.

[56] Alexandrov, A., Babakus, E. and Ugur, Y. (2007), "The effects of perceived management concern for frontline employees and customers on turnover intention, moderating role of employment status", Journal of Service Research, 9(4) 356-71

[57] Meyer, J. P., \& Allen, N. J. (1991). A three-component conceptualization of organizational commitment. Human resource management review, 1(1), 61-89. 